\section{Reforms Of The Social Sphere In The Cities Of The Southern Regions Of Uzbekistan And Their Results}

Tursunov A.S. Researcher Of Department "World History", Termed State University, Uzbekistan

\section{G OPEn ACCESS}

The American Journal Of Applied Sciences

JULY 2020

Page No.: 72-75

Volume-II Issue-VII

PUBLISHED: 30 JULY 2020

www.usajournalshub.com/inde x.php/tajas

Copyright: Original content from this work may be used under the terms of the Creative Commons Attribution 4.0 licence.

\title{
Abstract
}

After the collapse of the USSR, like other Soviet republics, a complete economic, sociocultural crisis in Uzbekistan is being tracked. These problems are clearly expressed in the cultural image of the cities of the republic, the quality of the provision of comunal services to the townspeople is deteriorating, the social security of low-income and large families, disabled people, etc. Is almost stopped. article provides information on the urbanization processes in Uzbekistan, the effectiveness of the reforms, ways to solve problems and problems in providing services to the urban population. The issue analyzes the effectiveness of the reforms implemented, methods of solving problems and in the provision of services, as well as social security of the urban population on the example of cities of southern regions.

Keywords: communal infrastructure, sports facilities, folklore and ethnographic ensemble, cultural institutions, reforms.

\section{Introduction}


From the first years of independence, difficulties and difficult situations began to arise in Uzbekistan in the social sphere. Problems in social relationships became apparent not only in Uzbekistan, but also in the republics of the former Soviet Union. The situation from the first days of independence was urgently brought under control, measures were taken to implement appropriate measures. In the old days, many planned things on the scale of the former Soviet Union remained unfulfilled. For example, Resolution No. 275 of 1990 of the Cabinet of Ministers of the Republic of Uzbekistan "On improving the provision of the population with drinking water and natural gas" is almost not implemented. There are many such examples in the pre-independence [1, p.17].During the years of independence, special attention was paid to the social protection of the urban population. Even with the beginning of the reform, the main goals were defined in it, which are aimed at creating decent conditions for human activity and life. With the beginning of the changes, the necessary measures for social protection of the population were considered in advance. For this purpose, cash payments in the form of wages, pensions, scholarships, and compensation began to be widely used, which were regularly changed. In 1991, in the cities of Surkhandarya region, the supply of the population with natural gas was $55.5 \%$. If the drinking water supply was $50 \%$, then by 2010 it reached $75.4 \%$ [2, p. 36].Provision of the population with drinking water and natural gas, considered a problem since the Soviet period, was included in the state program for the first time in the years of independence. The provision of work for the labor force, which was growing rapidly in the cities of Surkhandarya and Kashkadarya in 1991-2000, was carried out mainly through the opening of new jobs. Providing work for the population, supporting low-income families and large families is a priority task of Uzbekistan's policy. In the cities of the southern regions, special attention was paid to improving the amenities of the population. In this regard, great positive changes have taken place in the city of Karshi during the years of independence.By February 2000, in the cities of Karshi, Shakhrisabz, Guzar, Mubarak, Kitab, the provision of the population with drinking water was $60 \%$, and with natural gas $22 \%[3$, p. ten $]$.

If the execution of the Resolution of the Cabinet of Ministers No. 275 is considered on the example of the cities of the Kashkadarya region, then it can be noted that during 19901993 more than $2000 \mathrm{~km}$ of gas pipelines and $1000 \mathrm{~km}$ of water pipes were laid and put into operation [4, p. 36].In 1990-1994 in the construction and industry of the city, 1 million 334 thousand prefabricated reinforced concrete products, 4200 million pieces of bricks, 557 thousand expanded clay were produced. In 1995, a fund for 4 billion 814 million soums was commissioned, capital funds for 7 billion 564 million soums were spent, construction and installation work was carried out for 4 billion 504 million soums. In 1995, residential buildings of 367 thousand $\mathrm{m} 2$ were built and commissioned [5, p. 49]. Having thought in advance about the fate of the younger generation in the cities, great work has been done. In 2009, based on the needs for establishing communication services in 
southern cities, establishing modern communication facilities and meeting the needs of the population, important practical work was carried out. In 2010, services to the population of Termez amounted to 330.0 million soums, which compared to 2008, the growth rate was $132.9 \%$. As a result of rendering services to the population, 48.8 million soums were used for personal needs, which increased by $160.5 \%$ compared to 2008 . When performing the types of services that were carried out thanks to Surkhandarya Telecom, the subdivision of the city of Termez, the profit amounted to 241.3 million soums $(120.9 \%)$, and the profit received for the services rendered to the population left 40.4 million soums $(169.3 \%)$, and the profit for the service provided by the state joint-stock company "Surkhondaryopochtasi" ("Surkhandarya post") of the city of Termez amounted to 88.7 million soums $(182.0 \%)$, and the profit for services to the population amounted to 8.4 million soums $(127,1 \%)[6.34]$. According to the labor exchange of the city of Karshi under the "Bandlik" ("Employment") program, 35303 new jobs were created in 2010, ie. $(100.3 \%)$. As well as the average wages of workers and employees of the cities of Shakhrisabz, Guzar, Mubarak, Kitabamounted to 15038 soums, which is $128.2 \%$ compared to 2008. By industry, the highest average salary was in industry - 16676 soums, in finance, loans, insurance and pensions - 16988 soums, in transport - 13964 soums, geology and hydrometeorology - 11729 soums, in household services - 12,650 soums [7, p. 31].During the transition to a market economy for the social protection of pensioners, 3 categories and the average pension were divided and began to increase in stages. If in Uzbekistan in 2003 the average pension was 15987 soums, then by 2006 it was equal to 37548 soums [8, p. 142]. On the eve of the 2700th anniversary of Karshi, the monument "El-yurt tayanchi", erected at the initiative of the First President in the center of the city, became one of the symbols of caring for the family. In the cities of the Kashkadarya region, a "Territorial program to support low-income families from sources of sustainable income" and a program "Family strength and comprehensive preparation of young people for family life" were developed. On the basis of the programs, 107.8 thousand low-income families, where children under 16 (18) years old were paid benefits in the amount of 18 billion 486.5 million soums. 14.9 thousand low-income families received material assistance in the amount of 1 billion 154.7 million soums. For the purpose of social protection of the population, 157 thus families spent 31 billion 884.4 million soums [9, p. 22]. All this is aimed at the development of national, spiritual values, the creation of a material base.

In 2006, the program for providing the population, based on handicrafts in cities, identified 28 jobs, thanks to the development of this industry in large industrial enterprises, the annual plan of job creation was $100 \%$ fulfilled. In 2006, new 4,647 jobs were created, of which 3,291 jobs were aimed at creating small businesses and private entrepreneurship, 1,228 jobs for construction, reconstruction of new facilities and expansion of activities, 128 jobs for social development and expansion of market 
infrastructure, new jobs.In the city of Termez during 2010, the turnover in the total retail price amounted to 89149.9 million soums, compared to 2005 this figure was $139.1 \%$. Including, according to the report of official organizations, it amounted to 31,223.0 million soums, compared to 2005 it is $156.3 \%$ and per capita accounts for $160.3 \%$, at current prices the population was provided with a trade service for 718.8 thousand soums[ $10, \mathrm{c}$. 55]. In conclusion, it can be noted that in the process of scientific analysis of urbanization processes, thanks to independence, the social and everyday appearance of cities began to change radically, which indicates the positive results of the new reforms being implemented.

\section{Reference}

1. State archive of Surkhandarya region. 45 f., 2 p., 18 documents.

2. State archive of the Surkhandarya region. $45 \mathrm{f}, 2$ p., 22 documents.

3. Materials of the main department of statistics of the Kashkadarya region for 1991-2005.

4. Current archive of the branch of the Presidential Office of the Republic of Uzbekistan in the Kashkadarya region. 829 p. 4 sec. 35 s.

5. Current archive of the branch of the Presidential Office of the Republic of Uzbekistan in the Kashkadarya region. 829 p. 1 sec. 88 sat.

6. State archive of Surkhandarya region. $313 \mathrm{f}, 1 \mathrm{~s}, 19 \mathrm{~d}$,

7. Materials of the main department of statistics of the Kashkadarya region. 2008-2010

8. Materials of the main department of statistics of the Surkhandarya region for 2008

9. Kashkadarya region in the years of independence (based on the brochure of President Islam Karimov"16-year independent path of development of Uzbekistan" view of the economic and social development of the region) / head of the team of authors A. Erkaev. T: Manaviyat. 2007.

10. Materials of the main department of statistics of the Surkhandarya region for 2010 